\title{
Determinant Factors of Using E-Election in Indonesia
}

\author{
Sari Ratih Nur Istiqomah \\ Department of Accounting \\ Airlangga University \\ Surabaya, Indonesia \\ sariratihnur22@gmail.com
}

\author{
Noorlailie Soewarno \\ Department of Accounting \\ Airlangga University \\ Surabaya, Indonesia \\ noorlailie@gmail.com \\ Isnalita \\ Department of Accounting \\ Airlangga University \\ Surabaya, Indonesia \\ isnalita@feb.unair.ac.id
}

\begin{abstract}
An Election is one of the implementations of democracy in Indonesia. However, the implementation of the election is coloured by fraud, which results in the election of less qualified parties. The purpose of this article is to determine the determinants of citizen use in the context of applying electronic electoral systems in Indonesia. This analysis aims to test the validity and linear regression with the test using SPSS using 205 respondents. This method is used due to its lack of complexity. The results of the study indicate that the influence of citizens' intention to use an electoral system is relative advantage, compatibility and trust in the internet. The findings of the study provide further insights to researchers, citizen and governments involved. The study contributes to the growing literature on an electronic election system from Indonesia's perspective (a developing country's perspective).
\end{abstract}

Keywords-electoral; electronic election; use of intention

\section{INTRODUCTION}

The House of Representatives (DPR) is planning the implementation of an electoral-based electoral system in elections in 2019 [1]. This plan refers to the success of some areas that have held village head elections using electronic voting systems (e-voting). However, this electronic-based electoral system does not yet have a clear legal umbrella in Indonesian legislation [2]. The implementation of elections at the village level can still be done based on local regulations [3]. Based on the phenomenon, I am interested in examining the intentions of active voters in Indonesia if the electronic electoral system is really done.

Research on electronic voting (e-voting) is still rarely done. The e-voting research was conducted by [4]-[7]. There were inconsistencies in the results of the variables studied in the study such as trust in internet (TI_I), perceived usefulness (PU), perceived ease of use (PEOU) and compatibility (CT). [5] and [6] found that trust in the internet had a significant effect on voter intentions for electronic voting (e-voting) while [4] and
[7] found that trust in internet has no significant effect on the intention to use electronic election (e-voting). Perceived usefulness significantly influenced the intention to use electronic election (e-voting) on research conducted by [4], [5] and [7] while [6] issued perceived usefulness of further analysis because perceived usefulness is combined with compatibility and relative advantage. Perceived ease of use also shows inconsistent results. [6] found that perceived ease of use significantly affected the intention to use electronic election (evoting) while [5] found the opposite. [4] and [7] issued a perceived ease of use from further analysis.

This study uses an e-government adoption model used by [6] to find out the intentions of citizens using an online voting system, if it is actually implemented in Indonesia. Research on the intention of citizens to conduct elections is still rare in Indonesia, so the results of this study can add literature on citizens' intentions on the implementation of electronic elections in Indonesia.

The subjects in this study were active voters in the general elections held in Indonesia because changes in the electoral system allegedly influenced their intention to conduct elections.

\section{LITERATURE REVIEW}

\section{E-Voting}

Internet usage trends are growing in all aspects of human life, including selection of leaders of a region / country. Seeing the success of the Philippines in electing elections over the last six years [8], the House of Representatives (DPR) is planning the implementation of an electoral-based electoral system in 2019 [1].

The definition of e-voting according to [7] is the mechanism of the voting process produced, sent to citizens who utilise webbased internet applications. [1] stated that there are three evoting scenarios planned for implementation in Indonesia. The 
scenarios are to apply e-voting to all regions, to reject the use of e-voting or to apply in certain areas deemed ready. The E-voting implementation plan in Indonesia reaps the pros and cons. Parties that support the implementation of e-voting believe that e-voting is capable of cutting bureaucracy and sound manipulation practices, while those opposed to the implementation of e-voting assume that the electoral system in Indonesia is a transparent and internationalised electoral system [9]. Given the security issues surrounding Internet transactions, would citizens, especially students, be willing to vote online? Do those citizens then prefer to vote online as opposed to the traditional way of voting? These questions will be explored using the adoption model of e-government [6].

\section{Diffusion of Innovation}

[10] defines diffusion as a process in which an innovation is communicated over a certain channel at all times to members of a social society. The construct of e-voting adoption research included in DOI research is relative advantage and compatibility [6]. [6] conclude that DOI focuses on technological and market characteristics by analysing organisations or individuals with a background in sociology, communication, policy and management information systems.

\section{Technology Acceptance Model}

[11] TAM is widely used to study user acceptance of information technology. Several studies have used TAM to evaluate the adoption of e-government users [6], [5]. According to TAM, perceived usefulness (PU) and perceived ease of use (PEOU) affect individual behavioural intentions to use the system, which determines actual usage. [6] concluded that TAM focuses on the perception and nature of technology by analysing individuals or non-users backed by the science of management information systems.

\section{A. Perceived Usefulness}

Perceived usefulness is defined as the extent to which a person believes that his performance will increase if using a particular system [11]. Trust is believed to increase one's intention to use a particular system. The more people believe that a system can improve its performance, the greater one's drive will be to use it again. [4], [5] and [7] suggest that perceived usefulness significantly affects the intention of a person to use e-voting. The electoral system in Indonesia requires that a voter must be registered in a permanent voter list (DPT) and the election can only be conducted in accordance with the domicile listed in the e-ID card [12]. Elections of heads of regions / countries in Indonesia are usually conducted on ordinary days, allowing a person to decide not to vote for working out of town [13]. This will reduce the level of participation of the elections [14] so that the use of e-voting is believed to increase voter turnout as the Philippines do [8]. The hypothesis that can be formulated from this is as follows:

H1: The higher PU level will be positively associated with higher levels of intent to use e-voting services.

\section{B. Perceived Ease of Use}

Perceived ease of use is defined as the extent to which one believes that a system minimises one's effort [11]. [6] shows that perceived ease of use significantly influences one's intention to use e-voting. If the e-voting system is easy to use, it's important that the e-voting system becomes intuitive, easy to navigate and presents the needs that enable someone to choose more quickly and easily [6]. The more a person believes that a system is able to minimise the effort spent then one's intention to use the system will be even greater. The hypothesis that can be formulated from this is as follows:

H2 : The higher PEOU level will be positively associated with higher levels of intent to use e-voting services.

\section{Relative Advantage}

[15] defines relative advantage as the extent to which innovation is perceived as better than the idea it displaces. In the current study, relative advantage is considered a point where voters believe elections using electronic systems will work better than traditional elections [4]. Prior empirical research on the adoption of empirical technologies has found relative advantage to be a significant factor, i.e. research conducted by [16] and [17] for the application of e-filing systems of online taxes and expenditures. The current study presents a relative advantage as a determinant of the application of e-voting systems. The more a person believes that the electronic election will run better than traditional elections, the greater one's intention will be to use the system. The hypothesis that can be formulated from this is as follows:

H3: A higher level of perceived relative gain will be positively associated with a higher level of intention to use e-voting services.

\section{Compatibility}

Compatibility is defined as the extent to which innovation is perceived to be consistent with the value, experience and needs of people who will adopt [10]. The more a person believes that the electronic election matches their mode of interaction, the greater that person's intention will be to use the system. Research conducted by [6] found that compatibility has a significant effect on intent to use e-voting systems. The hypothesis that can be formulated from the above is as follows: H4: Higher compatibility rates will be positively associated with higher levels of intent to use e-voting services.

\section{E. Trust in Internet}

[6] and [18] define trust in the internet as a belief in an institution where trust is required structurally to increase the probability of achieving successful results such as e-commerce [19]. The more one believes in internet network security, the greater their intention will be to use the system. Research conducted by [6] shows that trust in internet has a significant influence on one's intention to use e-voting system. The hypothesis that can be formulated from the above is as follows: H5: Higher trust rates on the internet will be positively associated with higher levels of intent to use e-voting services. 


\section{F. Trust in Government}

[18], [20], [21] define trust in government as public trust in government, based on their perception of the integrity and ability of the government to deliver services in accordance with the expectations held by citizens. Research conducted by [4], [5], [6] and [7] show that trust in government has a significant influence on one's intention to use the e-voting system. The more a person believes that the government is able to organise electronic elections well beyond traditional elections, then the greater one's intention will be to use e-voting systems. The hypothesis that can be formulated from the above is as follows: H6: A higher level of trust in government will be positively associated with higher levels of intent to use e-voting services.

\section{RESEARCH METHOD}

This study surveys young people to gain perceptions about electronic voting. By administering surveys, we can get responses from relatively large young groups. The population used in this study is the citizens who have become active voters in the general election in Indonesia. A criterion sample research is a resident who never got a computer lesson and uses the internet more than 1 hour every day. The data is obtained after delivering the questionnaire to 215 respondents. A total of 7 responses were excluded from the sample because they never received a computer lesson, 1 response was excluded because they never received computer lessons and used the internet for less than 1 hour every day; 2 responses were issued twice, so the final sample of this study was 205 responses.

This study uses surveys to examine the various factors that influence e-voting adoption. Factors suspected to influence evoting adoption are relative advantage, compatibility, perceived usefulness, perceived ease of use, trust in the internet and trust in government. Intent to use e-voting is used as the basis for measuring e-voting adoption. Questionnaires are used to collect the necessary information related to the factors that influence evoting adoption. The survey items were adapted from previous research by [6]. Responses to statements in the research questionnaire were measured on a five-point Likert scale (interval scale) ranging from 1 (strongly disagree) to 5 (strongly agree).This study model is tested using the multiple regression analysis and analysed using SPSS 20.0. This method is used because the model used is not too complicated.

\section{RESULTS AND DISCUSSION}

\section{A. Reliability and Validity Test}

Analysis using KMO (Kaiser-Meyer-Olkin Measure of Sampling Adequacy) is done to determine whether there is correlation between variables. The value should show a value $>$ 0.50 for a factor analysis. KMO values are as recommended by [22] so that factor analysis can be done. SPSS are grouped into 25 (twenty five) indicators i.e. 3 PU, 3 PEOU, 5 RA, 4 CT, 3 TI_I and 4 TI_G into four factors based on value eigen value> 1, i.e. factor 1 with eigen value 12,732, factor 2 with eigen value 1.693, factor 3 with eigen value1,543 and factor 4 with eigen value 1.207. CT3, CT4 and RA3 were excluded from the analysis because of inconsistent factor groupings.

For reliability test, the requirements used are Cronbach Alpha $>0.60$ [22]. Based on the results, the reliability test using Cronbach alpha showed PU (0.790), PEOU (0.762), RA (0.851), CT (0.918), TI_I (0.863) and TI_G (0.916) so reliability test was achieved.

TABLE I. MULTIPLE REgRESSION RESUlTS

\begin{tabular}{|ccccc|}
\hline No & Variable & Coefficient & Sig & Support \\
1. & PU & 0,040 & 0,631 & No \\
2. & PEOU & $-0,163$ & 0,053 & No \\
3. & RA & 0,311 & 0,006 & Yes \\
4. & CT & 0,303 & 0,000 & Yes \\
5. & TI_I & 0,252 & 0,000 & Yes \\
6. & TI_G & 0.023 & 0.746 & No \\
\hline
\end{tabular}

\section{B. Multiple Regression Analysis}

Since the main purpose of this study was to examine the relationship between e-government adoption (dependent variable) and factor (independent variable), multiple regression was considered as the most suitable analytical technique.

The regression produced a model with adjusted $\mathrm{R}$ of 62.2 percent. This indicates that 62.2 percent of independent variables can explain the variation of the dependent variable (intention to use e-election). Intention to use e-voting adoption is significantly influenced by RA $(\beta=0.311, \mathrm{p}<0.01)$; CT $(\beta=$ $0,303, p<0,01)$ and TI_I $(\beta=0.252, p<0.01)$. The most powerful factor is Relative Advantage (RA). Therefore, H3, H4 and $\mathrm{H} 5$ are supported. Furthermore, H1, H2 and $\mathrm{H} 6$ are not supported, as PU $(\beta=0.040, \mathrm{p}>0.05), \operatorname{PEOU}(\beta=-0.163, \mathrm{p}>$ $0.05)$ and TI_G $(\beta=0,023, p>0,05)$ do not play a significant role in influencing the intention to use electronic voting services.

\section{Discussions}

Only RA, CT and TI_I constructs are found to have a significant effect on intent to use electronic voting services. RA is the most significant influence factor on the intention to use electronic voting services to show results that are in line with research conducted by [17]. These results suggest that relative advantage has a significant influence on citizens' intentions to use electoral systems. Offering the ease of choosing anywhere in the system can increase the perception of relative advantage, which may lead to an increase in users. It may also be advantageous to only show prospective voters the benefits of choosing to use the system. Citizens who fill out this questionnaire believe that electronic voting systems are considered better than conventional electoral systems because of their more flexible nature. In addition, the electronic voting system will make it easier for election supervisors to minimise fraud.

CT also has a significant effect on the intention to use electronic voting services. These results are in line with research conducted by [6] and [5], which show that 
compatibility has a significant effect on citizens' intentions to use electronic electoral systems. These results indicate that citizens' intentions to use electronic voting systems will increase if the electoral system matches the way citizens interact in their daily lives [6]. Intensity of citizens using the internet for more than 3 hours a day shows that citizens tend to interact more with the internet; so it can be said that the internet has become a way for someone to interact with other citizens. The phenomenon that is often found today is when some people gather, they are interacting with their gadgets more so than interacting with people who are there.

TI_I also has a significant effect on the intention to use electronic voting services. These results are in line with research conducted by [6] and [5], which show that trust in internet has a significant influence on citizens' intentions to use electronic electoral systems. It is shown that citizens believe that the internet in Indonesia is in a safe condition because when Wannacry Ransomware affects the internet environment around the world, Indonesia is able to minimise the impact of Wannacry ransomware by issuing several steps to avoid it [23]. Even in 2014, Indonesia ranks 13th out of 193 countries as it relates to internet security, at its internet security level is set by the world telecommunication body or ITU [24].

PU has no significant effect on the intention to use electronic voting services. This result is in line with research conducted by [25] which suggests that perceived usefulness has no significant effect on citizens' intentions to use electronic electoral systems. This can happen because the prospective voters in Indonesia assume that the electronic electoral system is difficult to use, because of the lack of a strong internet network in Indonesia, thus, making the possibility of interference very large. In addition, the internet network in Indonesia has not evenly spread to remote areas, so disruption may occur during the implementation of the electronic election especially in the remote area. The lack of an uneven Internet network in Indonesia can be caused by the development of Indonesia's telecommunication infrastructure, which is not optimal [26].

PEOU has no influence on the intention to use electronic voting services. This result is in line with research conducted by [5] which suggests that perceived ease of use has no significant effect on citizens' intentions to use electronic electoral systems. The high intensity of internet use by citizens makes them confident in their ability to use the internet [5]. The more often a person uses a technology, the more he will become used to it and find ease in doing so.

Finally, the result reveals that TI_G has no influence on intention to use electronic voting services. This result is not in line with research conducted by [5] which shows that trust in government has a significant influence on citizens' intention to use the electronic electoral system. This is likely due to the increasingly alarming level of corruption in Indonesia. The implementation of e-election requires substantial funding and the public lacks trust in the government due to the corruption phenomenon of state projects by state officials that continue to appear. These include e-KTP corruption cases resulting in the slow service of making ID cards, so many citizens cannot follow the election because they do not have e -KTP.

\section{CONCLUSION AND LIMITATIONS}

This study was conducted to examine the factors that determine citizens' intentions to use electronic electoral systems. The results show that relative advantage, compatibility and trust in internet perceptions are significant indicators of citizens' desire to use electronic election systems. Knowledge of the factors that influence adoption will enable government agencies to develop online services that meet the needs of their citizens. The study also highlights the importance of conducting research with a wide diversity of respondents.

Limitation in this study is the limited number of respondents involved in the study to examine the factors that influence the citizens' intention to use the electronic electoral system; as such, the results obtained less than the maximum. For further research, researchers should increase the number of samples used so that the results can represent all Indonesian citizens. In addition, predictor variables that influence the intention to use e-election can be added to subsequent studies, such as complexity and perceived of image.

\section{REFERENCES}

[1] N. R. Hakim, "Perlukah penerapan "E-Voting" pada Pemilu di Indonesia? [Is it Necessary to Implement E-Voting on Elections in Indonesia?]" Kompas.com, 2017. [Online]. Available: https://nasional.kompas.com/read/2017/01/13/09373191/perlukah.pener apan.e-voting.pada.pemilu.di.indonesia. [Accessed: Nov. 17, 2017].

[2] "Siap Digunakan, Sistem e-voting Tergantung Payung Hukum [Ready to Use, e-Voting System Depends on Legal Protection]," - JPNN.com, JPNN.com, 2014. [Online]. Available https://www.jpnn.com/news/siap-digunakan-sistem-e-votingtergantung-payung-hukum. [Accessed: Nov. 29, 2017]

[3] "BPPT Tunggu Payung Hukum e-Voting [BPPT Waits for e-Voting Legal Protection],” Tribunnews.com - Tribunnews.com, 2017. [Online]. Available:http://www.tribunnews.com/nasional/2017/03/22/bppttunggu-payung-hukum-e-voting. [Accessed: Nov. 17, 2017].

[4] M. Alomari, P. Woods, and K. Sandhu, "Predictors for e-government adoption in Jordan," Inform. Technol. \& People, vol. 25, no. 2, pp. $207-$ 234, 2012.

[5] L. C. Schaupp and L. Carter, "E-voting : from apathy to adoption," J. of Enterprise Inform. Manage., vol. 18, no. 5, pp. 586-601, 2005.

[6] L. Carter and F. Bélanger, "The utilization of e-government services : Citizen trust, innovation and acceptance factors.," Inform. Syst. J., vol. 15, no. 1, pp. 5-25, 2005.

[7] M. K. Alomari, "E-voting adoption in a developing country," Transf. Gov.: Peo., Proc. and Pol., vol. 10, no. 4, pp. 526-547, 2016.

[8] Suhendra, "Plus Minus e-Voting untuk Pilkada Indonesia [Positive and Negative Sides of e-Voting for Indonesia's Regional Election]," in Tirto.ID. 2016. [Online]. Available: https:tirto.id/plus-minus-e-votinguntuk-pilkada-indonesia-bNoN. [Accessed: Nov. 22, 2017]

[9] A. Mardiastuti, "Pro-Kontra e-Voting, Mendagri: Keputusan di Penyelenggara Pemilu [Pros and Cons of e-Voting, Interior Minister: The Decision is on the Election Organizer]," detikNews.com. 2017. [Online]. Available: https://news.detik.com/berita.3447511/pro-kontra-e-votingmendagri-kepurusan-di-penyelenggara-pemilu. [Accessed: Nov. 23, 2017]

[10] E. Rogers, Diffusion of Innovations. New York: The Free Press, 1995.

[11] F. D. Davis, "Perceived usefulness, perceived ease of use, and user acceptance of information technology," MIS Quart., vol. 13, no. 3, pp. 319-340, 1989.

[12] N. Purnamasari, "Catat! Panduan bagi Pemilih yang Terdaftar dan Tak Terdaftar di DPT [Take a Note! Guidance for Registered and Unregistered Voters in the Permanent Voter List]," in detik, 2017. 
[Online]. Available: https://news.detik.com/berita/d-3422133/catatpanduan-bagi-pemilih-yang-terdaftar-dan-tidak-terdaftar-di-dpt. [Accessed: Nov. 23, 2017]

[13] M. Ayodia, "Fenomena Golput dan Penyebabnya [Abstentions Phenomenon and its Cause]," in Kompasiana.com, 2014. [Online]. Available: https://kompasiana.com/ayodiamahardika/fenomena-golputdan-penyebabnya_54f76e5ea3331145338b484c. [Accessed: Nov. 17, 2017]

[14] "Dibanding Tahun 2009, Angka Golput Pemilu 2014 Lebih Rendah [Compared with 2009, Abstentions Statistics in 2014 are Lower]," in detikNews, 2014, [Online]. Available: https://news.detik.com/berita/2578828/dibanding-tahun-2009-angkagolput-pemilu-2014-lebih-rendah. [Accessed: Nov. 16, 2017].

[15] E. M. Rogers, Diffusion of Innovations. New York: The Free Press, 1983.

[16] A. Ojha, G. P. Sahu, and M. P. Gupta, "Antecendents of paperless income tax filing by young professionals in India: an exploratory study," Transf. Gov.: Peo., Proc. and Pol., vol. 3, no. 1, pp. 65-90, 2009.

[17] C. van Slyke, C., F. Belanger, and C. L. Comunale, "Factors influencing the adoption of web-based shopping: the impact of trust.," ACM Sigmis Database, vol. 35, no. 2, pp. 32-49, 2004.

[18] F. Bélanger and L. Carter, "Trust and risk in e-government adoption," The J. of Strategic Inform. Syst., vol. 17, no. 2, pp. 165-176, 2008.

[19] D. H. McKnight, V. Choudhury, and C. Kacmar, "Developing and validating trust measures for e-commerce: an integrative typology," Inform. Syst. Res., vol. 13, no. 3, pp. 334-359, 2002.

[20] M. Levi, and L. Stoker, L., "Political trust and trustworthiness," Ann. Rev. of Pol. Sci., vol. 3, no. 1, pp. 475-507, 2000.
[21] F. D. Schoorman, R. C. Mayer, and J. H. Davis, "An integration model of organizational trust," Acad. of Manage. Rev., vol. 20, no. 3, pp. 709734, 1995.

[22] I. Ghozali, Aplikasi analisis multivariate dengan program SPSS [Application of multivariate analysis using SPSS program]. Semarang: Badan Penerbit Universitas Diponegoro, 2006.

[23] O. Yusuf, "Begini cara menangkal serangan ransomware wannacry [How to Prevent WannaCry Malware Attack]," in Kompas.com, 2017, [Online]. Available: http://tekno.kompas.com/read/2017/05/13/19170047/begini.cara.menan gkal.serangan.ransomware.wannacry. [Accessed: Nov. 29, 2017]

[24] F. Anjungroso, "Keamanan internet Indonesia di urutan ke-13 [Indonesian internet security ranked $13^{\text {th }}$ ]," in Tribunnews.com, 2014, [Online].

Available: http://ribunnews.com/techno/2014/12/15/keamanan-internet-indonesiadiurutan-ke-13. [Accessed: Nov. 29, 2017]

[25] C. Phonthanukitithaworn, C. Sellitto, and M. W. Fong, M. "An Investigation of Mobile Payment (m-Payment) Service in Thailand," Asia-Pac. J. of Bus. Admin., vol. 8, no. 1, pp. 37-54, 2016.

[26] Gusti, "Universitas Gadjah Mada: Penetrasi Internet Belum Merata [Gadjah Mada University: Internet Penetration is not Evenly Distributed]," in UGM, 2016. [Online]. Available: https://ugm.ac.id/id/berita/12372-penetrasi.internet.belum.merata. [Accessed: Nov. 29, 2017]. 